\section{Poinsettia Cultivars Differ in Their Response to Molybdenum Deficiency}

\author{
Douglas A. Cox \\ Plant and Soil Sciences, Stockbridge Hall, University of Massachusetts, \\ Amherst, MA 01003
}

Additional index words. Euphorbia pulcherrima, trace elements, nitrate reductase, plant nutrition

\begin{abstract}
Six cultivars of poinsettia (Euphorbia pulcherrima Willd. ex Kl.) were grown in unlimed growth medium consisting of equal volumes of sphagnum peat and perlite. Plants received fertilizer solutions supplying Mo at either 0.0 mg-liter ${ }^{-1}(-M o)$ or 1.0 mg.liter $^{-1}(+M o)$. In the - Mo treatment, moderate to severe symptoms of Mo deficiency (marginal and interveinal chlorosis, marginal necrosis, and downward curling of the margins) developed on the middle-aged and some recently matured leaves of 'Annette Hegg Brilliant Diamond' and 'Eckespoint Lilo', while some interveinal chlorosis occurred on the same leaves of 'Gutbier V-17 Angelika'. No symptoms appeared on 'Gross Supjibi', 'Peace Regal Velvet', and 'Peace Noel'. All cultivars were symptomless in the + Mo treatment. In the -Mo treatment, upper, recently matured leaves of the symptomatic cultivars and two of three symptomless cultivars had Mo concentrations at or near the critical level for deficiency; however, nitrate reductase enzyme activity was higher and $\mathrm{NO}_{3}-\mathrm{N}$ was lower in the leaves of symptomless cultivars than of symptomatic cultivars.
\end{abstract}

The development of interveinal chlorosis on leaves of poinsettia is a common cause of reduced plant quality during commercial production. Deficiency of the micronutrient Mo has been identified as one cause of interveinal chlorosis in poinsettia (Jungk et al., 1970). The susceptibility of poinsettia to Mo deficiency appears to be unique among floriculture crops. Foliar symptoms of Mo deficiency on poinsettia generally occur on the upper (young) and middle-aged leaves and, in addition to interveinal chlorosis, include marginal necrosis and downward curling of the leaf margins. Nitrate reductase enzyme activity (NRA) is inhibited and $\mathrm{NO}_{3}-\mathrm{N}$ accumulates in the leaves of Mo-deficient plants, including poinsettia (Cox, 1988). Poinsettias are most likely to develop Mo deficiency when they are grown in soilless growth media of low $\mathrm{pH}(<5.5)$ and when Mo-containing fertilizer is not used or is applied in insufficient quantities (Cox, 1988; Jungk et al., 1970).

Information regarding the susceptibility of poinsettia cultivars to Mo deficiency is limited and often anecdotal. However, Jungk et al. (1970) found that under growth medium conditions favorable for Mo deficiency 'Annette Hegg' and 'Paul Mikkelsen' developed severe interveinal chlorosis, but 'Eckespoint C-1 Red' was symptomless. Cox (1988) reported similar results: 'Annette Hegg Brilliant Diamond' and 'Gutbier V-14 Glory' developed symptoms of Mo deficiency, but

Received for publication 6 Sept. 1991. Accepted for publication 29 Apr. 1992. Paper no. 3050 of the Massachusetts Agricultural Experiment Station. I thank Paul Ecke Poinsettias and Ball Seed Co. for donation of plant material and W.R. Grace and Co. for donation of fertilizer. The cost of publishing this paper was defrayed in part by the payment of page charges. Under postal regulations, this paper therefore must be hereby marked $a d$ vertisement solely to indicate this fact.
'Eckespoint C-1 Red' did not, when plants were grown in an acidic soilless medium with no Mo fertilization.

Some new poinsettia cultivars have recently been released. As a result, the number of cultivars with potentially different phenotypic and cultural requirements has expanded since earlier research was conducted on cultivar response to Mo nutrition. The objective of this research was to identify poinsettia cultivars most likely to develop symptoms of Mo deficiency and to study the differences between cultivars in leaf tissue $\mathrm{Mo}, \mathrm{NO}_{3}-\mathrm{N}$, and NRA.

Rooted terminal cuttings of 'Annette Hegg Brilliant Diamond' (AH), 'Gross Supjibi' (SJ), 'Gutbier V-17 Angelika' (GV), 'Eckespoint Lilo' (EL), 'Peace Regal Velvet' $(\mathrm{RV})$, and 'Peace Noel' (PN) were obtained from commercial propagators for this experiment. All cultivars have red bracts but otherwise differ in phenotype and some cultural requirements. AH has been widely grown commercially since 1979 (Ecke et al., 1990) and readily shows Mo deficiency symptoms (Cox, 1988); the other cultivars were introand their response to Mo deficiency is unknown. Cuttings were potted in 1.5-liter (15$\mathrm{cm}$ diameter) pots between 28 July and 4 Aug. 1988. The growth medium consisted of equal volumes of sphagnum peat and perphate $/ \mathrm{m}^{3}$ and $21 \mathrm{~g}$ chelated iron $/ \mathrm{m}^{3}$. Limestone and trace element fertilizer were omitted to create conditions favorable for the development of Mo deficiency. The $\mathrm{pH}$ of the medium at planting was 3.3 ; at the termination of the experiment $\mathrm{pH}$ was 4.2. Plants were fertilized at every watering with a solution containing $\left(\mathrm{mg} \cdot \mathrm{liter}^{-1}\right) 300 \mathrm{~N}, 300 \mathrm{~K}$, and $24 \mathrm{Mg}$ from calcium nitrate, potassium nitrate, and magnesium sulfate, respectively. duced to the trade between 1987 and 1988, lite amended with $4.7 \mathrm{~kg}$ single superphos-
Micronutrients, except Mo, were added to the fertilizer solutions according to Hoagland and Arnon (1950). Molybdenum levels were $0.0 \mathrm{mgliter}^{-1}(-\mathrm{Mo})$ and $1.0 \mathrm{mg} \cdot$ liter $^{-1}$ (+Mo). The experiment was a completely randomized design, with five single-plant replicates of each cultivar per Mo treatment. Plants were grown in a glasshouse at $\approx 21 /$ 17C (day/night) under natural photoperiod. Plants were pinched to four to five nodes 23 Aug. A single foliar spray of daminozide at $2500 \mathrm{mg} \cdot$ liter $^{-1}$ was applied to all plants 5 Oct. to control height.

On 5 Dec., a clear day, three to four upper recently matured leaves were sampled at 1100 $\mathrm{HR}$, transported to the laboratory on ice, and assayed for NRA, which was determined using the in vivo technique of Jaworski (1971) adapted by Cox (1988) for assaying poinsettia tissue. The experiment was completed on 7 Dec., at which time remaining upper recently matured leaves were sampled for Mo and $\mathrm{NO}_{3}-\mathrm{N}$ analyses and shoots were cut at the growth medium surface for dry weight determination. Plant material was dried in a forced-air oven at 54C. Dried leaf tissue was ground to pass a screen with $425-\mu \mathrm{m}$ openings (40-mesh) and analyzed for Mo by the thiocyanate calorimetric procedure described by Greweling (1976), and $\mathrm{NO}_{3}-\mathrm{N}$ was determined potentiometrically (Mills, 1980). Data were subjected to analysis of variance, and cultivar effects were analyzed using mean separation.

In the -Mo treatment, moderate to severe foliar symptoms of Mo deficiency occurred on $\mathrm{AH}$ and EL, less-severe symptoms occurred on GV, and no symptoms occurred on SJ, RV, and PN. Leaves of AH and EL showed interveinal chlorosis, followed by the development of marginal necrosis and some downward curling of the margins. Symptoms occurred on middle-aged and some recently matured leaves. Interveinal chlorosis on AH and EL became apparent 10 to 11 weeks after pinching. In the case of GV, symptoms were limited to the recently matured leaves and appeared as interveinal chlorosis beginning at the leaf margin and spreading toward the middle of the leaf $\approx 1$ to $2.5 \mathrm{~cm}$. Symptoms were readily apparent on GV, but only at the end of the experiment. Application of Mo-containing fertilizer solution in the + Mo treatment prevented the occurrence of Mo deficiency symptoms on all cultivars. Shoot dry weight (data not shown) was affected by Mo treatment only for $\mathrm{AH}$; the shoots of $-\mathrm{Mo}$ plants of this cultivar weighed $\approx 20 \%$ less than those of + Mo plants $(P=0.05)$.

Molybdenum concentration in the leaves sampled from symptomatic and symptomless cultivars (except RV) in the -Mo treatment was at of near the critical level of $0.5 \mu \mathrm{g} \cdot \mathrm{g}^{-1}$ suggested by Ecke et al. (1990) (Table 1). Leaves of RV contained more Mo than those of the other cultivars, and the concentration was near the normal range of $1-5 \mu \mathrm{g} \cdot \mathrm{g}^{-1}$ suggested for poinsettia by Ecke et al. (1990). The application of Mo-containing fertilizer solution increased Mo in the leaves of all cultivars compared with -Mo, but the in- 
Table 1. Effect of Mo and cultivar on the appearance of Mo deficiency symptoms and concentrations of $\mathrm{Mo}$ and $\mathrm{NO}_{3}-\mathrm{N}$ in poinsettia leaves.

\begin{tabular}{|c|c|c|c|c|c|c|c|c|}
\hline \multirow[b]{2}{*}{ Cultivar } & \multicolumn{2}{|c|}{$\begin{array}{l}\text { Mo deficiency } \\
\text { symptoms }\end{array}$} & \multicolumn{3}{|c|}{ Tissue Mo $\left(\mu \mathrm{g} \cdot \mathrm{g}^{-1}\right)$} & \multicolumn{3}{|c|}{ Tissue $\mathrm{NO}_{3}-\mathrm{N}(\%)$} \\
\hline & $-\mathrm{Mo}$ & $+\mathrm{Mo}$ & $-\mathrm{Mo}$ & $+\mathrm{Mo}$ & Significance & - Mo & $+\mathrm{Mo}$ & Significance \\
\hline \multicolumn{9}{|l|}{ Annette Hegg Brilliant } \\
\hline Diamond & Yes & No & $0.49 b^{2}$ & $0.98 a b$ & * & $1.02 \mathrm{a}$ & $0.44 \mathrm{~b}$ & $* *$ \\
\hline Gross Supjibi & No & No & $0.54 \mathrm{~b}$ & $1.73 \mathrm{a}$ & $* *$ & $0.79 \mathrm{~b}$ & $0.72 \mathrm{a}$ & NS \\
\hline Gutbier V-17 Angelika & Yes & No & $0.59 \mathrm{~b}$ & $1.69 \mathrm{a}$ & $* *$ & $0.79 \mathrm{~b}$ & $0.72 \mathrm{a}$ & NS \\
\hline Eckespoint Lilo & Yes & No & $0.66 \mathrm{ab}$ & $0.98 \mathrm{ab}$ & NS & $1.00 \mathrm{a}$ & $0.48 \mathrm{~b}$ & $* *$ \\
\hline Peace Regal Velvet & No & No & $0.99 \mathrm{a}$ & $1.02 \mathrm{ab}$ & NS & $0.40 \mathrm{c}$ & $0.47 \mathrm{~b}$ & NS \\
\hline Peace Noel & No & No & $0.52 \mathrm{~b}$ & $0.74 \mathrm{~b}$ & NS & $0.54 \mathrm{c}$ & $0.51 \mathrm{~b}$ & NS \\
\hline
\end{tabular}

${ }^{2}$ Mean separation within columns by Duncan's multiple range test, $P=0.05$.

, $*$, ** Mo effects nonsignificant or significant at $P=0.05$ or 0.01 , resepctively.

Table 2. Effect of Mo and cultivar on nitrate reductase activity (NRA) in poinsettia leaves.

\begin{tabular}{lccc}
\hline \hline & \multicolumn{2}{c}{ NRA (nM NO$/ g$ fresh wt per hour) } & Significance \\
\cline { 2 - 3 } Cultivar & $-\mathrm{Mo}$ & $+\mathrm{Mo}$ & $* *$ \\
\hline Annette Hegg Brilliant & & & \\
$\quad$ Diamond & $71 \mathrm{~d}^{\mathrm{z}}$ & $344 \mathrm{bc}$ & NS \\
Gross Supjibi & $178 \mathrm{c}$ & $255 \mathrm{c}$ & $* *$ \\
Gutbier V-17 Angelika & $85 \mathrm{~d}$ & $442 \mathrm{~b}$ & *** \\
Eckespoint Lilo & $100 \mathrm{~d}$ & $373 \mathrm{bc}$ & NS \\
Peace Regal Velvet & $568 \mathrm{a}$ & $791 \mathrm{a}$ & NS \\
Peace Noel & $388 \mathrm{~b}$ & $386 \mathrm{bc}$ & \\
\hline
\end{tabular}

${ }^{2}$ Mean separation within columns by Duncan's multiple range test, $P=0.05$.

${ }^{\text {Ns }}$,**Mo effects nonsignificant or significant at $P=0.01$, respectively.

crease was significant only for $\mathrm{AH}, \mathrm{SJ}$, and $\mathrm{GV}$. Leaves of all cultivars, except PN, in the +Mo treatment had a Mo concentration at or within the normal range for poinsettia. There were few significant differences in Mo concentration among cultivars in the $+\mathrm{Mo}$ treatment, but SJ and GV leaves contained more Mo than leaves of PN.

More unassimilated $\mathrm{NO}_{3}-\mathrm{N}$ accumulated in the leaves of symptomatic cultivars than symptomless cultivars in the -Mo treatment (Table 1). Comparing -Mo and + Mo treatments, addition of Mo to the fertilizer solution resulted in significantly less accumulation of $\mathrm{NO}_{3}-\mathrm{N}$ in the leaves of $\mathrm{AH}$ and $\mathrm{EL}$ but had no effect on accumulation in the other cultivars. Regardless of Mo treatment or cultivar, $\mathrm{NO}_{3}-\mathrm{N}$ concentration exceeded the level of $0.3 \%$ that Ecke et al. (1990) suggested as reflecting Mo deficiency in poinsettia. $\mathrm{NO}_{3}$ $\mathrm{N}$ accumulation in plant tissue is influenced by factors other than Mo nutrition. Rate of applied $\mathrm{N}$ fertilizer (Cantliffe et al., 1974), light intensity (Cantliffe, 1972a), and photoperiod and time of day of tissue sampling (Cantliffe, 1972b) affect tissue $\mathrm{NO}_{3}-\mathrm{N}$ levels. In the current study, the high levels of $\mathrm{NO}_{3}-\mathrm{N}$ found in the leaves probably resulted from the frequent application (two to three times per week) of fertilizer solutions supplying a moderate to high rate of $\mathrm{N}$ exclusively in the $\mathrm{NO}_{3}-\mathrm{N}$ form.

In the -Mo treatment NRA was higher in leaves from SJ, RV, and PN than leaves sampled from cultivars showing symptoms (Table 2). NRA of symptomatic, but not symptomless, cultivars was significantly in- creased by +Mo treatment.

Results of this study show that there is a difference among poinsettia cultivars in their susceptibility to foliar symptoms caused by Mo deficiency. Of the six cultivars tested, $\mathrm{AH}, \mathrm{EL}$, and GV developed symptoms when grown in unlimed soilless medium with no Mo fertilization. SJ, RV, and PN were symptomless under the same conditions. The conditions created in this experiment are unlikely to occur very often in commercial practice, because most poinsettia producers recognize the importance of adequate liming and micronutrient fertilization of soilless growth media. Since interveinal chlorosis can be caused by nutrient disorders other than Mo deficiency, such as excess ammoniumnitrogen (Boodley, 1970) and deficiencies of Mg (Cox and Seeley, 1983) and Mn (Lenanton, 1969), these causes should also be considered when making a diagnosis.

The Mo concentration in leaves sampled from plants grown in the -Mo treatment was near the currently accepted critical level in the symptomatic cultivars and two of three symptomless cultivars (RV had a Mo concentration higher than the others). Although there was little difference among most cultivars in Mo concentration in the -Mo treatment, NRA levels were lower and $\mathrm{NO}_{3}-\mathrm{N}$ concentrations were higher in the leaves of cultivars showing symptoms than in leaves from symptomless cultivars. Similar results were obtained in earlier research where Cox (1988) found that leaves of symptomless 'Eckespoint C-1 Red' had the same Mo concentration as leaves from symptomatic cul- tivars, but NRA was higher and $\mathrm{NO}_{3}-\mathrm{N}$ concentration was lower in the symptomless cultivars. Taken together, these results suggest that poinsettia cultivars differ in the amount of Mo they require to avoid disruption of $\mathrm{NO}_{3}-\mathrm{N}$ metabolism. Interveinal chlorosis in symptomatic cultivars may be the result of an inadequate supply of reduced $\mathrm{N}$ for chlorophyll formation caused by diminished NRA.

\section{Literature Cited}

Boodley, J.W. 1970. Nitrogen fertilizers and their influence on the growth of poinsettias. Flor. Rev. 147:26-27, 69-73.

Cantliffe, D.J. 1972a. Nitrate accumulation in spinach grown under different light intensities. J. Amer. Soc. Hort. Sci. 97:152-154.

Cantliffe, D.J. 1972b. Nitrate accumulation in vegetable crops as affected by photoperiod and light duration. J. Amer. Soc. Hort. Sci. 97:414418.

Cantliffe, D.J., G.E. MacDonald, and N.H. Peck. 1974. Reduction in nitrate accumulation by molybdenum in spinach grown at low $\mathrm{pH}$. Commun. Soil Sci. Plant Anal. 5:273-282.

Cox, D.A. 1988. Lime, molybdenum, and cultivar effects on molybdenum deficiency of poinsettia. J. Plant Nutr. 11:589-603.

Cox, D.A. and J.G. Seeley. 1980. Magnesium nutrition of poinsettia. HortScience 15:822-823.

Ecke, P., Jr., O.A. Matkin, and D.E. Hartley. 1990. The poinsettia manual. 3rd ed., Paul Bcke Poinsettias, Encinitas, Calif.

Greweling, T. 1976. Chemical analysis of plant tissue. Cornell Univ. Agr. Expt. Sta. Search. Agron. 6.

Hoagland, D.R. and D.I. Arnon. 1950. The waterculture method of growing plants without soil. Calif. Agr. Expt. Sta. Circ. 347.

Jaworski, E.G. 1971. Nitrate reductase assay in intact plant tissues. Biochem. Biophys. Res. Commun. 43:1274-1279.

Jungk, A., B. Malaheb, and J. Wehrmann. 1970. Molybdenum deficiency on poinsettias, a cause of leaf damage. Gartenwelt 17:31-35.

Lenanton, J.H. 1969. Interveinal chlorosis of poinsettias. M.S. Thesis, Univ. of California, Davis.

Mills, H.A. 1980. Nitrogen specific ion electrodes for soil, plant, and water analysis. J. Assn. Offtc. Anal. Chem. 63:797-801. 